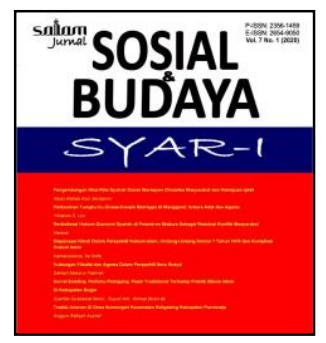

\author{
SALAM \\ Jurnal Sosial dan Budaya Syar-i \\ P-ISSN: 2356-1459. E-ISSN: 2654-9050 \\ Vol. 8 No. 1 (2021), pp. $1-20$ \\ DOI: 10.15408/sjsbs.v8i1.19383 \\ http://journal.uinjkt.ac.id/index.php/salam/index
}

\title{
Etika Bisnis Unit Usaha Pesantren \\ (Studi Kasus Pondok Pesantren Sahid Bogor dan Pondok Pesantren Ummul Qura' Al-Islami Bogor)*
}

\author{
Dwi Irfan Cahyo ${ }^{1}$ \\ Universitas Ibn Khaldun Bogor, Indonesia \\ do \\ $\underline{10.15408 / \text { sjsbs.v8i1.19383 }}$
}

\begin{abstract}
Ethics in Islamic business cannot be separated, because without it there will be confusion in determining the truth in doing business and there will be many crimes in business, thus the purpose of this study is to determine the application of business ethics in the pesantren business unit. The research methodology used is qualitative descriptive with a case study of the Sahid Bogor modern Islamic boarding school and also the Ummul Qura al-Islami Islamic boarding school in Bogor. The results of the study indicate that Islamic boarding school is able to apply business ethics through Islamic boarding school business unit as a place for Islamic teaching values and values as well as the principles of business ethics as materials that can be taught to teacher, student and the community around Islamic boarding school.
\end{abstract}

Key words: Islamic business ethics, business units, Islamic boarding school

\begin{abstract}
Abstrak
Etika dalam bisnis Islam tidak dapat terpisahkan, karena tanpanya akan menjadikan kerancuan dalam menentukan kebenaran dalam berbisnis serta akan terjadi banyak kejahatan dalam bisnis. Dengan begitu tujuan penelitian ini adalah untuk mengetahui penerapan etika bisnis pada unit usaha pesantren. Metodologi penelitian yang digunakan berupa kualitatif deskriptif dengan studi kasus pondok pesantren modern Sahid Bogor dan juga pondok pesantren Ummul Qura al-Islami Bogor. Hasil dari penelitian menunjukkan bahwa pesantren mampu menerapkan etika bisnis melalui unit usaha pesantren sebagai wadah dan nilai ajaran Islam serta prinsip etika bisnis sebagai bahan yang dapat diajarkan kepada asatidz dan santri serta masyarakat sekitar pesantren.
\end{abstract}

Kata kunci: Etika bisnis Islam, Unit usaha, Pesantren

* Received: December 12, 2020, Revision: December 18, 2020, Published: January 23, 2021.

${ }^{1}$ Dwi Irfan Cahyo adalah Mahasiswa Program Pascasarjana Universitas Ibn Khaldun Bogor, Jawa Barat, Indonesia. Email: dwiirfancahyo94@gmail.com. 


\section{A. PENDAHULUAN}

Dalam Islam, bisnis adalah serangkaian kegiatan ekonomi sebagai pemenuhan kebutuhan hidup, namun harus didasari dengan etika bisnis yang sesuai dengan ajaran Islam. ${ }^{2}$ Etika merupakan komitmen untuk melakukan apa yang benar dan menghindari apa yang salah. ${ }^{3}$ Dalam Islam, etika bermakna khuluq yang berarti tabiat budi perketi untuk menciptakan kehendak dan i'tikad yang menjadi kesadaran dan perangai manusia. ${ }^{4}$ Etika bisnis adalah seperangkat nilai tentang baik dan buruk, salah dan benar dalam bisnis yang berdasarkan pada moral. ${ }^{5}$ Gambaran etika bisnis Islam sebagai norma etika yang dasarnya adalah Qur'an dan hadits Rasul dimana mengatur tingkah laku individu dan kelompok. ${ }^{6}$

Pesantren merupakan lembaga pendidikan untuk pembentukan karakter religious Islam yaitu paham akan nilai Islam dan ketuhanan serta karakter mandiri yaitu percaya diri, mampu bekerja sendiri, menguasai keahlian, menghargai waktu, bertanggun jawab. ${ }^{7}$ Karakter mandiri mampu menghasilkan karakter wirausaha di pesantren melalui metode pengarahan, pendisiplinan, pembiasaan, suasana kondusif dan integrasi nilai pesantren. ${ }^{8}$ Namun karakter di pesantren tidak akan mampu berjalan tanpa modernitas seorang kyai/pimpinan dalam membawa arah dan tujuan pesantren. 9 Dengan berasaskan pada hadits nabi yang artinya "bekerjalah untuk duniamu seolah-olah kamu akan hidup selama-lamanya dan bekerjalah untuk akhiratmu seolah-olah kamu akan mati besok pagi" (Hr. Al baihaqi). ${ }^{10}$ Maka muncullah etos kerja Islam dari karakter yang bertujuan untuk kesejahteraan setiap individu, keluarga dan masyarakat dan dalam suatu negeri. ${ }^{11}$ Jadi pesantren mampu membentuk karakter wirausaha.

Karakter wirausaha mampu menciptakan sumber daya handal dan tangguh di era global. Ia mampu mendorong pesantren untuk mendirikan unit usaha sebagai

\footnotetext{
2 Busra Febriyarni, (2016), fiqh al-hadis etika bisnis (tinjauan kesahihan dan pemahaman), al istinbath: jurnal hukum islam, vol. 1, no. 2. Hal 142.

3 Dewi maharani, penerapan kejujuran dan tanggung jawab dalam etika bisnis syariah pada wirausaha muslim di kecamatan medan marelan, hal 21, Diakses dari http://jurnal.umsu.ac.id/index.php/intiqad/ article/view/1079.

${ }^{4}$ Baiq el-badriaty, (2018), implikasi nilai-nilai etika pada bisnis perspektif al-qur'an dan al-hadits, profit: jurnal kajian ekonomi dan perbankan, vol. 2, no.1. Hal 22

5 Kataruddin tiakoly, (2019), penerapan etika bisnis islam pada usaha pedagang barang campuran di pasar tradisional gamalama, jurnal iqtisaduna, vol.5, no.1. Hal 105.

6 Irsadunas dkk, (2018), tinjauan etika bisnis islam dalam pengelolaan corporate social responsibility, jebi (jurnal ekonomi dan bisnis islam), vol. 3, no. 2. Hal 147

7 Dian popi oktari dan aceng kosasih, (2019), pendidikan karakter religius dan mandiri di pesantren, jurnal pendidikan ilmu sosial, vol. 28, no. 1. Hal 47

${ }^{8}$ Riza zahriyal falah, (2018), membangun karakter kemandirian wirausaha santri melalui sistem pendidikan pondok pesantren, jurnal tarbawi vol. 15. No. 2. Hal 125

9 Agus eko sujianto, (2011), modernitas kyai dan implikasinya terhadap pendidikan kewirausahaan di pondok pesantren, millah vol. Xi, no. 1. Hal 159

10 Rahmad annam, (2015), etos kerja dan produktivitas kerja dalam upaya menjawab permasalahan ekonomi islam (perilaku mendapatkan uang/harta), al-masharif, vol. 3, no.2. Hal 39

${ }^{11}$ Mia fitriah elkarimah, (2016), etos kerja islami dalam mewujudkan kesejahteraan sosial, annuha vol. 3, no. 1. Hal 106
} 
tempat untuk berlatih dan mengajarkan karakter tersebut. ${ }^{12}$ Unit usaha di pesantren mampu mendorong perekonomian, sehingga dapat mensejahterakan dan juga memiliki kemaslahatan bagi pesantren. ${ }^{13}$ Jadi dengan adanya unit usaha, pesantren mampu memiliki kemadirian ekonomi.

Dalam Islam tujuan berusaha adalah memperoleh kesejahteraan dunia dan akhirat. ${ }^{14}$ Bekerja ataupun berusaha merupakan upaya dalam memenuhi kebutuhan diri sendiri dan keluarga. ${ }^{15}$ Namun terkadang manusia lupa akan tujuan tersebut dan melakukan tindakan di luar dari etika Islam, sehingga melakukan segala cara dalam memenuhi kebutuhan. ${ }^{16}$ Maka diperlukan penanaman etika yang baik dan harus tetanam kuat.

Melalui pendidikan, masyarakat mengetahui bagaimana beretika dalam usaha. Salah satu etika bisnis adalah memiliki sifat jujur, amanah, menyampaikan kebaikan, professional, serta mengeluarkan sebagian harta untuk sedekah. ${ }^{17}$ Karena dengan adanya etika bisnis, maka seseorang mampu kontrol dan kelola serta evaluasi setiap tindakan yang dilakukan didalam bisnis.

Salah satu tempat/lembaga yang mampu menerapkan pendidikan karakter dalam berusaha/bekerja yang berasaskan etika Islam adalah pondok pesantren. Maka masyarakat yang terdidik dalam berusaha mampu mendapatkan kesejahteraan di dunia dan akhirat. Terdapat beberapa pesantren yang memiliki unit usaha pesantren dan sudah berjalan lebih dari 5 tahun di daerah kabupaten bogor, diantaranya: pondok pesantren modern Sahid Bogor dan pondok pesantrren modern Ummul Qura al-Islami Bogor. Tujuan penelitian ini untuk mengetahui penerapan etika bisnis unit usaha pondok pesantren modern Sahid Bogor dan pondok pesantrren modern Ummul Qura al-Islami Bogor.

\section{B. METODE PENELITIAN}

Penelitian yang dilakukan penulis berupa penelitian kualitatif dimana hasil penelitian tidak diperoleh melalui prosedur statistik. Adapun jenis penelitian yang dilakukan berupa studi lapangan, dimana peneliti mengamati dan berpartisipasi secara langsung di lokasi pengambilan data dalam skala kecil atau besar.

12 Zaenal afandi, (2019), strategi pendidikan entrepreneurship di pesantren almawaddah kudus, bisnis: jurnal bisnis dan manajemen islam, vol. 7, no. 1. Hal 62

13 Dewi fatmasari, peran kewirausahaan dalam pemberdayaan ekonomi pesantren (sekilas tentang pesantren ainurrafiq) desa panawuan, kecamatan cigandamekar kabupaten kuningan, Hal 367, Di akses pada http://syekhnurjati.ac.id/jurnal/index.php/amwal/article/download/263/232

${ }^{14}$ Nurul ichsan, (2015), kerja, bisnis dan sukses menurut islam, the journal of tauhidinomics vol. 1 no. 2. Hal 169

${ }^{15} \mathrm{Hj}$. Norvadewi, (2014), profesionalisme bisnis dalam islam, mazahib : vol. Xiii, no. 2. Hal 175

${ }^{16}$ Khusniati rofiah, (2014), urgensi etika di dalam sistem bisnis islam, justitia islamica, vol.11, no. 2. Hal 4

17 Rizka ar rahmah, (2016), etika dan manajemen bisnis islam (studi kasus di waroeng steak and shake cabang sm raja medan), j-ebis vol. 2, no. 2. Hal 4-5 
Penelitian ini mengambil data sebagai bahan untuk penelitian berupa: pendapat dan jawaban dari proses wawancara yang dilakukan peneliti terhadap ketua dan pengelola setiap unit usaha pesantren

Objek penelitian adalah titik perhatian suatu penelitian yang hendak diteliti agar mendapatkan data yang terarah. Adapun sebagai tempat yang digunakan peneliti untuk diambil datanya, yaitu:

\section{1). Pondok pesantren Sahid Bogor}

Pondok pesantren Sahid bogor beralamat di Cibatok 2, Kec. Cibungbulang, Bogor, Jawa Barat 16630, Pondok Pesantren Modern Sahid terletak di Desa Gunung Menyan Pamijahan Bogor Jawa Barat.

\section{2). Pondok Pesantren Ummul Qura Al-Islami Bogor}

Pondok Pesantren Ummul Qura Al-Islami Bogor beralamat di Jl. Moh Noh Noer Rt.004/004 Kp. Banyusuci Ds. Leuwimekar Kec. Leuwiliang Bogor 16640 Jawa Barat.

\section{HASIL ANALISIS DAN PEMBAHASAN}

\section{Etika bisnis Islam}

Pandangan Islam terhadap kehidupan sebagai kesatuan yang utuh dan tidak terpisahkan, sehingga aspek ekonomi termasuk bisnis sangat penting peranannya dalam menyejahterakan hidup manusia. ${ }^{18}$ Dalam sejarahnya, nabi Muhammad sebagai Rasulullah dan suri tauladan muslim dalam segala hal, ia seorang pedagang yang mana mengajarkan etika bisnis kepada umatnya, ${ }^{19}$ serta memberikan aturan dalam berbisnis. ${ }^{20}$

Bisnis dalam Islam adalah perniagaan berdasarkan etika dan aturan agama, serta bukan hanya mengejar keuntungan dan keberuntungan perdagangan secara hakiki di dunia dan berlanjut di akhirat nanti. ${ }^{21}$ Sedangkan etika dalam Islam adalah akhlaq. ${ }^{22}$ Esensi dari misi nabi sebagai utusan allah, ${ }^{23}$ sebagimana Allah berfirman: "Dan tiadalah Kami (Allah) mengutus engkau (Muhammad) kecuali untuk menjadi rahmat bagi semesta alam" (QS. Al-anbiya 21/107).

Etika bisnis Islam merupakan akhlaq dan moral dalam melakukan transaksi perdagangan yang sesuai dengan ajaran Islam dan memiliki 2 ciri utama: pertama

${ }_{18}$ Andi darussalam, (2015) paradigma bisnis islam perspektif hadis, tahdis, vol. 6, no. 1. Hal 23.

${ }^{19}$ Suwandi, (2017) commerce ethics of muhammad pbuh' and universal values in era of prophet hood, jurnal ekonomi syariah indonesia, vol.vii, no.1. Hal 59

${ }^{20}$ Chaibou issoufou, (2015), review aticle significance of islamic business ethics, international journal of current research, vol. 7, issue. 11. Hal 23364.

${ }^{21}$ Rodliyah khuza'i, (2005), etika bisnis dalam persektif islam, mimbar, vol. Xxi, no. 1. Hal 47.

${ }_{22}$ Adibah binti abdul rahim, (2013), understanding islamic ethics and its significance on the character building, international journal of social science and humanity, vol. 3, no. 6. Hal 508.

${ }^{23}$ Maimoona saleem, ayaz khan and muhammad saleem, (2018), business ethics in islam, the dialogue, vol. Xiii, no.3. Hal 329 
tidak menetang fitrah manusia, kedua rasional. ${ }^{24}$ Nilai-nilai etika dan moral bisnis harus selalu dilandasi saling percaya, saling menguntungkan kedua belah pihak dalam praktik perniagaan. ${ }^{25}$ Adapun etika bisnis dalam Islam berbeda, karena berdasarkan aqidah, bertujuan dunia-akhirat, adanya profit dan zakat serta berkah. ${ }^{26}$

Etika bisnis dalam Islam bersumber dari al-Quran dan hadits dimana penerapannya perlu dilakukan ijtihad sesuai dengan dinamika perkembangan kultur zaman. ${ }^{27}$ Maka bagi pengusaha/pelaku bisnis harus mengikuti aturan dan etika bisnis Islam dengan tidak melakukan penipuan, pelecehan, dan sebagainya, yang akhirnya menyebabkan keruntuhan ekonomi Islam dan mengancam kesejahteraan umum masyarakat sebagaimana terkandung dalam al-Quran dan hadits. ${ }^{28}$

Prinsip merupakan dasar dalam berkehendak pada etika bisnis. Adapun prinsip etika bisnis, diantaranya: ${ }^{29}$

Pertama, Tauhid. Ia merupakan mengesakan Allah dalam uluhiyah, rububiyah dan nama-nama serta sifat-sifat allah. ${ }^{30}$ Ia merupakan inti daripada ajaran Islam serta menjadi dasar seluruh konsep dan aktivitas ummat Islam, sedang implikasinya terhadap kehidupan manusia. ${ }^{31}$

Secara singkat dapat dipahami, bahwa tauhid merupakan cara pandang hidup muslim dalam menjalankan aktivitasnya, sehingga mampu menemukan kebenaran. ${ }^{22}$ Maka, jika seseorang telah sampai pada tauhid sebagai pandangan hidup dalam etika bisnis Islam, sampai seseorang menjalankan aktivitas hidupnya sesuai dengan yang diatur oleh Allah, itulah yang dimaksud kesatuan/tauhid dan akan menemukan kebenaran. ${ }^{33}$

Kedua, keseimbangan adalah sunnah Allah dan salah satu esensi ajaran Islam, mencakup keseimbangan fisik dengan mental, atau material dengan spiritual akan menciptakan kesejahteraan holistik bagi manusia. ${ }^{34}$ Prinsip keseimbangan

${ }^{24}$ Muthmainnah. Md dan nursyamsu, (2017), landasan hukum islam: etika bisnis syariah dan faktor pengembangannya, jurnal syariah, vol. V, no. 1. Hal 61.

${ }^{25}$ Windari, (2015), perdagangan dalam islam, al-masharif, vol. 3, no. 2. Hal 20

${ }^{26}$ Muhammad ardi, (2015) etika bisnis dalam ekonomi islam, jurnal syari'ah, vol. Iii, no. 1. Hal 55.

${ }^{27}$ Hasyim nawawi, (2013), islamic business ethics between reality and history, karsa, vol. 21 no. 1. Hal 96

${ }^{28}$ Che mohd zulkifli and che omar ana siti sarpina saripuddin, (2015), concept of business ethics in islam - approach to the entrepreneur, journal of asian business strategy, vol. 5, no. 1. Hal 13

${ }^{29}$ Zahrotul wakhidah, (2017) pengaruh penerapan etika bisnis islam terhadap customer retention pada baitul māl wat tamwil (bmt) tumang boyolali, tesis, magister ekonomi, pascasarjana institut agama islam negeri (iain) surakarta. Hal 28

${ }^{30}$ Ifdlolul maghfur, (2016), membangun ekonomi dengan prinsip tauhid, jurnal malia, vol. 7, no. 2. Hal 215

${ }^{31}$ Elida elfi barus, (2016), tauhid sebagai fundamental filsafah ekonomi islam, jurnal perspektif ekonomi darussalam, vol. 2, no. 1. Hal 69

${ }_{32}$ M. Hasbi, (2009), konsep tauhid sebagai solusi problematika pendidikan agama bagi siswa madrasah, insania,vol. 14,no. 2 . Hal 6

${ }^{33}$ Lukman fauroni, (2003), rekonstruksi etika bisnis: perspektif al-qur'an, iqtisad journal of islamic economics, vol. 4, no. 1. Hal 91-105

${ }^{34}$ Mursal dan Suhadi, (2015), implementasi prinsip islam dalam aktivitas ekonomi: alternatif mewujudkan keseimbangan hidup, jurnal penelitian, vol. 9, no. 1. Hal 81-82 
dimaksudkan untuk memberikan keseimbangan antara kepentingan konsumen, pelaku usaha, dan pemerintah dalam arti materiil ataupun spiritual. ${ }^{35}$

Keseimbangan dalam etika bisnis Islam terbagi menjadi beberapa hal, diantaranya: Pertama, produksi dengan terpenuhinya kebutuhan dharuriyah dan memperhatikan ekosistem alam; Kedua, Konsumsi dengan melihat kebutuhan dan keinginan, serta menghindarkan diri dari mengkonsumsi barang haram, boros, berlebih-lebihan dan perhatian kepada orang lain; Ketiga, distribusi dengan tidak adanya ketidak seimbangan di pasar; Keempat, keuangan dengan larangan riba. ${ }^{36}$

Ketiga, kebebasan (free will) yaitu manusia bebas tidak sebebas-bebasnya, tetapi ada batasan atauran dari Allah, sebagai wakil (khalifah) Allah di bumi dan makhluk yang dianugerahi kehendak bebas dan terarah. ${ }^{37}$ Kebebasan yang dimiliki manusia perlu untuk memperoleh maslahat yang tertinggi dari pengelolaan dan pemanfaatan sumberdaya yang ada pada kekuasaannya untuk mencapai kesejahteran di dunia dan akhirat. ${ }^{38}$ Adapun penerapan kehendak bebas dalam etika bisnis dengan adanya hak khiyar (memilih) antara penjual dengan pembeli untuk melanjutkan transaksi atau membatalkannya selama keduanya belum berpisah. ${ }^{39}$

Keempat, tanggung jawab adalah perbuatan manusia secara sadar yang bersifat kondarati, dimana setiap manusia menanggung tanggung jawabnya masing-masing. ${ }^{40}$ Dengan begitu, tanggung jawab yang diemban oleh masing-masing orang menjadi kewajiban bagi dia untuk melaksanakan aktivitas sesuai dengan aturannya, sebagaimana dalam aturan bisnis Islam. ${ }^{41}$

Kelima, kebenaran yang dalam prakteknya terbagi dua sesuai sifat: pertama mutlak, sesuai dengan anggapan setiap orang; kedua relatif yang menghasilkan subjektifitas, namun kebenaran hakiki dilahirkan dari filsafat dan agama. ${ }^{42}$ Sedangkan dalam Islam, intuisi menjadi salah satu sumber kebenaran sebagaimana rasio dan

${ }^{35}$ Iffaty nasyi'ah, (2014), prinsip keadilan dan keseimbangan dalam penentuan nilai tukar barang (harga) perspektif islam dan hukum perlindungan konsumen, de jure, jurnal syariah dan hukum, vol. 6, no. 2. Hal 121-122

36 Wartoyo, (2018), etika bisnis islam: konstruksi nilai keseimbangan dan kemanusiaan, al-amwal, vol. 10, no. 2. Hal 236-243

37 Anti wulan agustini, (2017), distribusi kekayaan dalam ekonomi syariah, tazkiya jurnal keislaman, kemasyarakatan \& kebudayaan, vol. 18, no. 2. Hal 162

${ }^{38}$ Rina desiana, noni afrianty, (2017), landasan etika dalam ekonomi islam, al-intaj, vol. 3, no. 1. Hal 126

${ }^{39}$ Andi darussalam, (2015) paradigma bisnis islam perspektif hadis, tahdis, vol. 6, no. 1. Hal 33

40 Elfi yuliani rochmah, (2016), mengembangkan karakter tanggung jawab pada pembelajar (perspektif psikologi barat dan psikologi islam), al murabbi, vol. 3, no. 1. Hal 36

${ }^{41}$ Zeynep arslan, (2008), islamic business ethics and its impact on strategic business decision making process of muslims, tesis, bba, marmara university. Hal 37

42 Saifuddin, (2008), kajian agama dan filsafat tentang kebenaran, islam futura, vol. Vii, no.2. Hal 74 
empiris. Bahkan kebenaran melalui intuisi ini dianggap lebih tinggi kedudukannya. ${ }^{43}$ Namun Allah menurunkan hikmah sebagai sumber dari kebenaran. ${ }^{44}$

\section{Kemandirian Ekonomi Pesantren}

Pondok Pesantren sebagai pusat pendidikan agama bagi para santri, tetapi juga merupakan roda penggerak ekonomi bagi masyarakat sekitar. ${ }^{45}$ Sistem pembelajaran ekonomi kreatif di pesantren mempunyai peranan penting yaitu tanggung jawab besar kepada masyarakat dalam menjalani hidup lebih gigih, lebih produktif serta tidak bergantung kepada orang lain. ${ }^{46}$

Pusat aktivitas kemandirian peantren adalah kegiatan dari masjid, maka ia berperan penting di masyarakat, diantaranya: tempat ibadah dan spiritual, Pendidikan dan pelatihan masyarakat, pusat informasi dan komunikasi, tempat menjamin keamanan, Balai kesehatan, tempat kaderisasi umat, pusat perekonomian, Pusat kepustakaan, identitas dan bukti peradaban umat. ${ }^{47}$ Maka tidak dapat dipungkiri lagi, bahwa adanya masjid bukan hanya sekedar untuk tempat ibadah saja, tetapi sangat potensial untuk pengembangan umat Islam.

Kegiatan yang berada di masjid sebagai nilai pendidikan. Nilai-nilai fundamental dalam kehidupan yang diajarkan melalui kegiatan masjid yang didasarkan pada: (1) tafaquh fi ad-din, (2) fullday school, (3) pendidikan integrative kolaborasi antara formal dan nonformal, (4) adanya keragaman, kebebasan, kemandirian dan tanggungjawab, (5) diajarkan bagaimana hidup bermasyarakat. Secara koheren, nilai tersebut menghasilkan olah pikir, olah hati, olahraga, serta olah rasa dan karsa seseorang atau sekelompok orang. ${ }^{48}$

Dalam perkembangannya, pesantren merupakan lembaga yang turut andil dalam menciptakan generasi masa depan yang spiritualis dan intelektualis serta mandiri. ${ }^{49}$ Sehingga sangat jelas bahwa pesantren punya peran penting di masyarakat.

Perekonomian perlu diwujudkan dalam dunia pesantren, karena pesantren memiliki kemiripan layaknya sebuah negara. Dalam pesantren terdapat SDA dan SDM

\footnotetext{
43 Amin hasan, (2012), menyusuri hakikat kebenaran: kajian epistemologi atas konsep intuisi dalamtasawuf al-ghazali, jurnal at-ta'dib , vol. 7, no. 2. Hal 190

${ }^{44}$ Syairil fadli, (2017), kritik seyyed hossein nasr terhadap klaim kebenaran modernisme, jurnal nalar, vol 1, no 1 . Hal 78

${ }^{45}$ Endang sudarsih, (2010), mengembangkan wirausaha di pondok pesantren, jsh jurnal sosial humaniorah, vol 3 no.1. Hal 70

${ }^{46}$ Mirshal mauludin dan tri widianti natalia, (2018), penerapan pendidikan ekonomi kreatif di pesantren sebagai sarana untuk menghasilkan pribadi wirausaha yang dilandasi nilai-nilai keagamaan, prosiding temu ilmiah iplbi. Hal 51

47 R. Taufiqurrochman, pendidikan masyarakat berbasis masjid. Hal 4-7, Diakses pada http://repository.uin-malang.ac.id/799/2/masjid.pdf

${ }^{48}$ Baehaqi, (2017), masjid sebagai sumber pembentukan kretivitas manusia berkarakter, rausyan fikr. Vol. 13 no. 1. Hal 1317

${ }^{49}$ Nadhira ulfa dan maftukhatusolikhah, (2015), minat wirausaha kaum santri dan faktor-faktor yang mempengaruhinya ( studi pada pondok pesantren ar-riyadh palembang), i-economics journal, vol.1, no.1. Hal 2
} 
yang baik. Oleh karena itu, pesantren bukan hanya sebagai lembaga dakwah Islam tetapi juga sebagai media dakwah ekonomi. ${ }^{50}$ Maka perekonomian berupa kemandirian ekonomi pesantren mampu meningkatkan ekonomi.

Dalam manajemen, pesantren memiliki 2 katagori akademik, yaitu: jiwa kepemimpinan dan kemandirian. Jiwa pemimpin lahir dari pendiriannya oleh Kyai, sedangkan mandiri yang anti penjajah yang kekuatannya dari kelembagaan Kyai dan dukungan masyarakat. ${ }^{51}$ Adapun orientasi kemandirian pesantren melalu 2 hal: pertama, ketiadaannya bergantung pada pihak eksternal dalam berbagai aktivitas, kedua, berada diatas dan untuk semua golongan dan memiliki kekuatan sosial potlitik diluar pesantren. ${ }^{52}$

Kemandirian ekonomi Pondok Pesantren, merupakan proses yang harus dikerjakan dengan nilai prestasi, dedikasi, loyalitas, totalitas dan tanpa cacat. Sehingga harus focus pada: ${ }^{53}$ a). Etos entreprenership pengelola ekonomi; b). Program-program profesionalisasi SDM; c). manajemen ekonomi yang baik; d). Kreatif dalam kualitas.

\section{Etika Bisnis Unit Usaha Pondok Pesantren Ummul Qura Al-Islami Bogor}

Karakter yang dimiliki oleh unit usaha pada pesantren Ummul Qura sebagai nilai landasan yang mempengaruhi aktivitas unit usaha dalam bisnis yaitu: pertama, nilai taawun yaitu saling membantu diantara penghuni pesantren; Kedua, mandiri dalam hal dana; Ketiga, adanya interaksi antar penghuni pesantren; Keempat, swadaya guru/asatidz sebagai bentuk pendanaan/investasi terhadap unit usaha pesantren; Kelima, wilayah internal dalam bisnis yaitu cangkupan bisnis yang dijalankan pesantren masih di sekitar pesantren; Keenam, nilai keikhlasan dalam transaksi; Ketujuh, nilai kejujuran bagi pengelola unit usaha guna mencegah dari bentuk pengkhianatan dalam berbisnis; Kedelapan, adanya wewenang penuh pengelola dari pesantren dalam pengelolaan sehingga adanya kebebasan bagi penanggung jawab dalam melakukan kebijakan meski tujuannya harus sama; Kesembilan, adanya fungsi belanja sambil beramal/sedekah; Kesepuluh, adanya pemenuhan kebutuhan santri dan pesantren

Pandangan pesantren terhadap unit usaha yang di jalankan pada lingkungan pesantren berupa sangat responsif terhadap unit usaha, karena dengan begitu kegiatan bisnis akan merasa ada dorongan penuh dari pesantren dengan begitu pengelola

\footnotetext{
${ }^{50}$ Ning purnama sariati dan binti mutafarida, (2019) pesantren dan konsumsi halal santri (studi kasus di pesantren syarif hidayatulah rejomulyo kediri), prosiding nasional,vol.2. Hal 19

${ }^{51}$ Kamaruddin, (2018), manajemen strategic pesantren dalam pengembangan kewirausahaan di yayasan darul yatama wal-masakin (dayama) jerowaru kecamatan jerowaru kabupaten lombok timur, tesis, program manajemen pendidikan islam, pascasarjana universitas islam negeri mataram. Hal 3-5

52 Zaini hafidh, badrudin, (2018), pesantren dan kemandirian perekonomian: studi tentang kewirausahaan di pondok pesantren ar-risalah cijantung iv ciamis, manageria: jurnal manajemen pendidikan islam, vol. 3, no. 2. Hal 261

53 Moh. Rifa'i, (2019), manajemen ekonomi mandiri pondok pesantren dalam mewujudkan kualitas layanan pendidikan, profit: jurnal kajian ekonomi dan perbankan, vol. 3, no. 1. Hal 37
} 
bersemangat dalam menjalankan bisnisnya. Jadi wujud unit usaha pesantren termasuk upaya dan wadah untuk pengembangan pesantren.

Dalam pengelolaannya pesantren telah melakukan semua prinsip etika bisnis dan fiqh muamalah, sebagaimana materi yang telah diajarkan dalam pesantren dan juga pengembangan ilmu bagi guru yang mengelola.

Adapun prinsip lain berupa: pertama dari santri ke pondok dan dari pondok untuk santri sebagai wujud timbal balik yang saling menguntungkan. Kedua sebagai ladang latihan dalam pengelolaan, pendidikan jual beli secara syariah tanpa paksaan dan juga pengetahuan akan tata cara dalam transaksi yang benar melalui jiwa trampil serta pendidikan santripreneur, ketiga adanya konsep hadiah kepada santri yaitu bentuk pemberian yang tidak perlu diharapkan sehingga santri tidak perlu ada niat untuk mencari penghidupan serta keuntungan dalam menjalankan usaha. Keempat harus tertulis hal apapun yang berupa barang dan keuangan sebab untuk menjaga kepercayaan. Kelima bentuk keharusan untuk mengikuti aturan pesantren karena berada di lingkungan pesantren. Keenam self service customer dimana konsumen memiliki kebebasan dalam memilih barang yang akan dibeli dan pengelola tidak berprasangka buruk terhadap prilaku yang dilakukan konsumen.

Adapun dampak etika bisnis pada unit usaha pesantren sangat bagus bagi pelaku serta menambah pengalaman bagi pelaku dalam pengetahuan transaksi dan inventaris barang yang diperdagangkan, maka pelaku bisnis merasa bahwa pesantren melalui unit usaha pesantren mampu menjadikan santri faham dalam beretika dalam bisnis.

Dalam penerapan etika bisnis unit usaha pesantren terdapat 3 hal yang menjadi tolak ukur peneliti, yaitu:

Pertama, pemahaman etika bisnis pada pelaku bisnis di pesantren, berupa: a). Penjelasan secara teori dan materi tentang unit usaha; b). Pemberian suri tauladan; c). Pengajaran perbedaan hal-hal yang baik dan buruk dalam unit usaha; d). Pengajian bersama mingguan sebagai motivasi dan pengetahuan bersama kyai; e). Pendidikan etika Islam berupa: sopan, sedekah, barang halal, pandangan usaha bukan pada orientasi materi; f). Pemahaman secara betul terhadap produk bagi pelaku sebagai keharusan sama tahu tentang produk melalui edukasi, pelatihan, musyawarah pemberian informasi dan rapat.

Kedua, pengarahan etika bisnis pada pelaku bisnis di pesantren, berupa: a). Arahan bahwa pelaku usaha harus rajin tanpa meninggalkan kewajiban belajar dan mencari ilmu di pesantren; b). Arahan amanah bagi pelaku untuk menjalankan aktivitas usaha; c). Saling membutuhkan antara guru pengelola dan santri pengelola karena keduanya saling memiliki kemampuan untuk mengembangkan unit usaha pesantren; d). Adanya rapat evaluasi bulanan sebagai wadah untuk saling mengingatkan; e). Motivasi belajar ilmu dan bisnis sebagai kader.

Ketiga, pengawasan etika bisnis pada pelaku bisnis di pesantren, berupa: kontrol harian kegiatan usaha secara langsung, penyetoran dana harian/berkala dalam 
laporan keuangan, terdapat badan pemeriksa keuangan dan guru muda sebagai supervisi dan penasehat dalam kegiatan unit usaha.

Dalam berkegiatan usaha, unit usaha di pesantren memerlukan tempat untuk usaha namun menyesuaikan dari pesantren, sedangkan stok barang selalu siap dalam penyediaan barang agar konsumen tidak kecewa saat barang di beli dan mampu melihat barangnya. Jadi hal ini yang di usahakan pesantren untuk berusaha/ bisnis.

Dalam pesantren, unit usaha tidak ada persaingan pasar karena konsumen dari santri dan merupakan bentuk kesejahteraan bersama penghuni pesantren karena saling membangun antar unit usaha serta bentuk pemahaman adanya keberkahan transaksi dalam pemanfaatan barang yang dijual. Unit usaha pesantren juga mampu memberi bantuan kepada masyarakat sekitar dan guru serta penghuni pesantren dalam menghindari praktek ribawi karena dilarang dalam agama Islam.

Adapun integrasi sistem bisnis di pesantren antara skill dan komputerisasi dan menyadarkan penghuni pesantren dan masyarakat untuk percaya dan belanja pada produk negeri sebagai fokus utama dalam pengembangan unit usaha untuk menghadapi persaingan. Namun terdapat persaingan ketat dalam harga barang, pelayanan maksimal kepada konsumen dan penawaran nilai sedekah serta delivery order jika go public, hal ini merupakan kewaspadaan dan harus memiliki kesiapan bagi unit usaha agar mampu berkembang luas.

Tujuan unit usaha pesantren, berupa: pertama kemandirian pesantren dari segi ekonomi karena sebagai penunjang pesantren dalam berkembang, kedua persaingan secara lokal jika tidak belum bisa global sebagai bentuk minimal perkembangan unit usaha pesantren.

Pemasaran sebagai ujung tombak bisnis meski di pesantren konsumen dari santri jadi tidak ada kompetitior, dengan begitu tidak ada kesusahan dalam produk pesantren dalam mengembangkan unit usaha melalui pemasaran, meski pemasaran seharusnya merupakan ujung tombak bagi sebuah bisnis. Maka tidak ada bentuk pemasaran secara meluas karena tidak mencari royalty dan pemasaran cuma melalui sosialisasi kepada guru dan pekerja meski masih lokal.

Meski demikian, dalam menunjang unit usaha pesantren, pemasaran tetap perlu untuk masyarakat sekitar melalui aplikasi alat komunikasi guna menjemput bola kemauan masyarakat karena tidak perlu datang berbelanja ke market namun barang bisa dikirim.

Dalam proses penetapan harga hasil produksi terdapat adanya harga hak cipta dalam produksi barang sehingga keuntungan produksi pada unit usaha pesantren tidak besar namun menyesuaikan, serta unit usah pesantren tidak ada penggandaan barang orang lain agar mendapatkan keberkahan, jadi hal inilah yang menjadikan pesantren beretika dalam produksi

Penentuan barang produksi unit usaha pesantren harus sesuai permintaan barang dan perkiraan permintaan tahun selanjutnya serta ada data base barang pokok dan request barang dari konsumen sebagai kebutuhan dan acuan belanja barang. 
Harga dan kualitas bagus namun sesuai ekonomi santri, dan produk yang dijual sesuai aturan pesantren. Inilah ketentuan dalam produksi barang di pesantren.

Dalam unit usaha pesantren terdapat siklus perputaran keuangan, yaitu: uang masuk dari pesantren atau investasi dari guru dan pekerja pesantren untuk beli barang, kemudian dijual kepada santri, dan laporan ke pimpinan serta rapat pemilik saham secara berkala, kemudian dengan adanya sistem keuangan yang komputerisasi maka tidak akan tercampur antara keuntungan dan modal.

Adapun kerugian tidak ada karena bisa dijual pada tahun berikutnya selama tidak ada perbedaan barang. Kebutuhan santri tinggi dan perputaran barang cepat, dan ada return barang sebelum masa berlaku barang habis, sehingga dapat meminimalkan kerugian, sedangkan dalam hal keuangan kemungkinan ada dari salah menghitung dan salah memberikan kembalian uang. Sedangkan keuntungan pasti selalu ada bagi unit usaha pesantren serta dapat di alokasikan dalam bentuk sedekah dan kesejahteraan pesantren.

Laporan keuangan yang dilakukan pesantren sangat mudah, yaitu berupa: debet, kredit, keuntungan untuk dilaporkan. Pengambilan keuntungan disesuaikan dari sumber barang, dan laporan keuangan secara sentralisasi kepada pimpinan, sehingga laporan tidak akan luput dari pimpinan.

\section{Etika Bisnis Unit Usaha Pondok Pesantren Modern Sahid Bogor}

Unit usaha pesantren dijalankan dengan nilai halal dan sehat, dimana pelakunya berusaha agar setiap barang yang digunakan untuk perdagangan/bisnis harus halal sesuai dengan ajaran agama Islam dan nilai pesantren dan sehat serta menyehatkan secara fisik. Lain daripada itu, unit usaha pesantren melakukan bisnis dengan tujuan akhirat atau ridho Allah yang mana bukan hanya sekedar untung dan rugi yang dicarinya, maka bisnis yang terjadi tidak semata-mata untuk kepentingan pribadi namun lebih kepada maslahah dan falah.

Unit usaha pesantren selalu bekerjasama dengan pesantren. Dalam tata kelola sudah ada program tersistem skala kecil dalam sistem bisnis yang menjadikan unit usaha pesantren memiliki karakteristik tiap unit usaha pesantren, namun terpisah antara unit pendidikan pesantren dan unit usaha pesantren dalam pengelolaan agar keduanya mampu dan bisa fokus setiap kegiatannya, maka wewenang pengelolaan diberikan kepada penanggung jawab unit unit usaha namun tetap melaporkan kegiatan kepada yayasan dan juga pelaku bisnis kebanyakan dari masyarakat dan sebagian dari guru. Adapun fokus utama dalam bisnis yaitu pemenuhan kebutuhan santri, sehingga membantu dan memudahkan santri dalam menjalankan kehidupan di pesantren.

Unit usaha pesantren sangat bersinergi dalam roda kehidupan pesantren. Dalam menjalankan bisnis, unit usaha pesantren tidak terlepas dari seluruh seluruh aktivitas kehidupan dan kebutuhan yang dimiliki pesantren, baik dari kalangan guru, santri, walisantri bahkan masyarakat sekitar, sehingga sinergi inilah yang mampu 
memberi kontribusi yang nyata bagi pesantren dan unit usaha untuk terus saling membantu dalam kemajuan keduanya.

Prinsip bisnis yang diterapkan pada unit usaha pesantren adalah sopan, ramah dan etika yang diajarkan di pesantren serta halal, sehat, sikap pelayanan yang humanis dan juga menutup aurat, sehingga bisnis yang dijalankan mampu untuk terus memberi yang terbaik kepada konsumen/ pelanggan.

Penerapan etika bisnis oleh pelaku melalui menjaga dan mengamalkan dengan kontrol dari pesantren dan juga evaluasi di setiap bidang usaha yang ada di pesantren. Hal inilah yang nantinya penanggung jawab usaha mampu melakukan kontrol usaha pada unit usaha pesantren.

Melalui berbagi ilmu, pelatihan, pengarahan usaha bulanan dan edukasi tentang motivsi kerja dan hal lain dalam bisnins serta etika bisnis yang disesuaikan dengan konsumen antara santri dan masyarakat yang mengikuti aturan pesantren, menjadikan hal tersebut sebagai cara menerapkan etika bisnis pada lingkup unit usaha. Hal inilah merupakan upaya unit usaha pesantren untuk terus eksis dalam melakukan bisnis pada tiap sektor yang dikelola oleh masing-masing unit usaha dan juga adanya komunikasi yang intens dari pihak pesantren dan pelaku bisnis/usaha yang baik, maka terjadilah penerapan yang efektif dalam pengelolaan unit usaha pesantren.

Pengawasan unit usaha dilakukan oleh penanggung jawab unit usaha agar lebih terarah serta dalam menjalankannya sesuai nilai pesantren dan ajaran Islam yang mana penanggung jawab unit usaha sudah pasti merupakan dari pihak pesantren yang paham akan nilai pesantren dan ajaran Islam dan juga dibantu oleh tim audit internal yayasan yang dilakukan secara berkala.

Dalam proses penerapan etika bisnis, unit usaha pesantren diberi pengetahuan secara berkala lewat pelatihan dan pengajian sebagai bentuk kontrol unit-unit usaha pesantren yang nantinya mampu untuk berjalan secara bersama dengan aktivitas pesantren.

Dalam bisnis biasanya ada persaingan, namun pada unit usaha pesantren dengan berinovasi tanpa menyingkirkan pesaing dan dengan melakukan penetapan harga atas kebijakan penanggung jawab unit usaha dan dari produsen, sehingga persaingan yang pasti terjadi bisa diminimalisir. Dengan begitu, unit usaha pesantren mampu dan bisa terus melakukan kegiatan bisnis.

Adapun tujuan utama unit usaha pesantren merupakan pemenuhan kebutuhan internal pesantren, sehingga konsumen utama bagi unit usaha pesantren adalah seluruh masyarakat yang berada di sekitar pesantren. Dengan begitu sasaran utama tidak akan melakukan persaingan secara berlebih antar unit usaha pesantren, namun akan lebih terjalin kerjasama ekonomi dan terciptanya keharmonisan dalam bisnis.

Cara yang dilakukan unit usaha pesantren untuk terus menghadapi dunia bisnis dalam persaingan adalah dengan memperkuat usaha yang ada serta berinovasi dan melihat peluang usaha yang mampu untuk dikelola pesantren yang berguna untuk menyediakan dan mencukupi seluruh kebutuhan masyarakat pesantren, jadi 
unit usaha pesantren tidak akan menjadikan persaingan sebagai ajang untuk saling menjatuhkan namun sebagai persaingan dalam kebaikan dan kerjasama ekonomi.

Dunia telah berkembang dan maju sampai penggunaan alat komunikasi sebagai alat bantu untuk usaha serta bisnis. Meski begitu unit usaha pesantren tetap harus ikut dengan perkembangan zaman dengan tanpa meninggalkan jati diri dari unit usaha pesantren, maka melalui dunia nyata yaitu promosi nyata dan dunia maya yaitu ada informatika kepada masyarakat, unit usaha pesantren mampu untuk terus melakukan pemasaran agar dapat mensosialisasikan barang yang dapat diperdagangkan di pesantren

Pemasaran yang dilakukan unit usaha pesantren, bukan hanya sekedar untuk memberikan informasi tentang barang yang bisa dikonsumsi oleh konsumen semata namun lebih daripada itu, agar lebih berkembang usaha pesantren dan menjadi syiar usaha yang Islami, sehingga masyarakat bukan hanya mendapatkan informasi yang bisa didengar dan dilihat namun bisa dirasakan dengan hati dan akal serta dilakukan secara ajaran Islam.

Cara yang dilakukan unit usaha pesantren dalam pemasaran yaitu perlahan tapi pasti dengan prinsip:

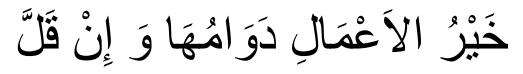

Yang artinya: sebaik pekerjaan adalah yang terus-menerus meski sedikit. Inilah yang menjadikan prinsip pemasaran bagi unit usaha pesantren, meski kecil dan sedikit tapi terus menerus/istiqomah/konsisten akan menjadikan unit usaha terus dikenal dan berkembang serta mampu mensyiarkan Islam.

Unit usaha yang dikelola pesantren bekerjasama dalam beberapa pihak dalam pengelolaannya, guna membantu dan ikut serta memenuhi kebutuhan barang produk bagi unit usaha. Jalinan kerjasama tersebut merupakan upaya unit usaha sehingga bisnis yang dikelola tidak hanya dengan keilmuan yang dimiliki oleh penanggung jawab namun adanya kolaborasi dalam pengelolaan dengan pihak lain.

Produksi yang dilakukan unit usaha pesantren semisal ternak lele bekerjasama dalam bentuk bibit dan pakan, dan juga sahid mart bekerjasama dalam bentuk stok barang dagang, sehingga unit usaha pesantren masih terus eksis hingga saat ini. Etika produksi yang dijalankan oleh pelaku harus sesuai dengan apa yang diarahkan oleh penanggung jawab dari pesantren, karena dengan begitu para pelaku dan juga badan pengelola yang bekerjasama dengan unit usaha pesantren harus mengikuti arahan yang telah dibuat oleh pihak unit usaha.

Proses yang diberlakukan dalam melakukan produksi barang pada unit usaha, yaitu: pertama peninjauan yang dilakukan oleh penanggung jawab disertai dengan pihak yayasan, kedua musyawarah dan mufakat antara pihak yayasan dan penanggung jawab yang kemudian segera ditindak lanjuti oleh penanggung jawab unit usaha pesantren sehingga selalu ada komunikasi antara pihak yayasan dan unit usaha dalam hal memproduksi barang. 
Dalam proses produksi barang, terdapat kontrol dan evaluasi berkala yang dilakukan oleh penanggu jawab dan pihak yayasan guna terus memantau terjadinya proses produksi ataupun stok barang pada unit usaha pesantren, dengan begitu barang yang diproduksi atau barang yang menjadi stok pada unit usaha pesantren tidak keluar dari barang yang dibutuhkan serta diperlukan oleh pesantren dalam memenuhi kebutuhan masyarakat yang berada di dalam dan di sekitar pesantren.

Secara umum, bisnis menghasilkan dana. Hal itu wajar dan perlu serta harus diketahui, maka adanya laporan keuangan langsung ke yayasan sesuai persetujuan dari penanggung jawab unit usaha merupakan cara yang dilakukan oleh unit usaha untuk terus menjaga kepercayaan terhadap yayasan. Adapun kerugian tidak pernah atau jarang terjadi pada unit usaha pesantren karena barang dapat dikonsumsi oleh masyarakat pesantren, sedangkan jika terjadi keuntungan maka alokasinya kembali ke unit usaha lagi.

Penanggung jawab unit usaha pesantren memiliki hak dan kewajiban untuk mengatur sendiri alur keuangan pengelolaan dana usaha pesantren oleh unit masingmasing, namun pelaporan keuangan tetap langsung kepada yayasan, sehingga yayasan memiliki kewajiban untuk merekap dan meninjau laju keuangan pada tiap unit usaha pesantren.

Yayasan dalam melakukan kegiatan penerimaan laporan keuangan tidak serta merta sendirian dalam menerimanya, namun bekerjasama dengan akuntan publik dalam mereview dan meninjau keuangan yang berjalan pada unit usaha pesantren, sehingga kepercayaan akan terus meningkat dan dana yang di kelola tidak mudah keluar tanpa adanya pengetahuan dari pihak yayasan.

\section{Analisa Hasil}

Setiap unit-unit usaha pesantren memiliki karakteristiknya masing-masing sesuai dengan ciri khas setiap pesantren dan juga fokus usaha pada setiap unit usaha. Pesantren yang sudah ada sejak lama di Indonesia dan berkembang di masyarakat sudah memiliki karakternya. Hal ini di picu dengan kesesuaian pada faktor keadaan sekitar dan disesuaikan dengan pendiri di setiap pesantren. Karakter inilah yang menjadikan setiap pesantren memiliki ciri-ciri sistem pendidikan.

Karakter pesantren yang dituangkan dalam unit usaha menjadikannya memiliki integritas dengan nilai dan jiwa yang telah diajarkan di pesantren, yang mana umumnya nilai Islam namun khususnya yaitu nilai kehidupan dalam prosesnya, sehingga masyarakat pesantren yang telah terdidik mampu serta bisa untuk mengamalkan pada unit usaha.

Unit usaha pesantren merupakan ikhtiar pesantren dalam mengembangkan dan memenuhi kebutuhan serta mengangkat dan menyadarkan perekonomian masyarakat sekitar sehingga terciptanya kemandirian ekonomi, yang mana nantinya dapat mensejahterakan masyarakat di pesantren 
Namun, meski berbeda di setiap pesantren dan di setiap unit usaha pesantren dalam hal bisnis. Pesantren terus melakukan proses sesuai dengan unit usaha yang dijalankan dalam pesantren sebagaimana kebutuhan yang dimiliki oleh pesantren. Bisnis tersebut telah dijalankan sesuai dengan nilai/moral yang diajarkan di setiap pesantren, dimana menjadi landasan bagi unit usaha dalam berbisnis dan beretika.

Dalam setiap unit usaha pesantren tujuannya tetap satu yaitu menerapkan nilai ajaran Islam dan prinsip dalam etika bisnis Islam. Unit usaha pesantren yang telah menjalankan bisnisnya telah mampu menjalankan produksi, persaingan usaha, pemasaran dan juga laporan keuangan sebagaimana etika yang telah diajarakan di pesantren karena adanya nilai/moral yang setiap harinya selalu diajarakan kepada seluruh masyarakat pesantren secara kondusif dengan cara/metode yang dimiliki oleh pesantren dalam pengajaran dan pendidikan.

\section{KESIMPULAN}

Berdasarkan hasil dari penelitian, maka dapat ditarik sebagai kesimpulan sebagai berikut:

Unit usaha pondok pesantren modern Sahid Bogor menerapkan ajaran Islam yang diajarkan oleh pesantren. Penerapannya dengan cara maksimal meski dengan proses yang tidak bisa sebentar. Etika yang diterapkan di mulai dari kepemilikan nilai Islam dan prinsip etika bisnis Islam kemudian adanya teknis penerapan, pengawasan dan juga kontrol yang etika bisnis Islam.

Kegiatan produksi, pemasaran, persaingan, laporan keuangan dalam unit usaha pesantren dilakukan dengan cara yang wajar sesuai dengan nilai Islam dan prinsip etika bisnis, meski dalam pengelolaan unit usaha pesantren memliki kerjasama dengan pihak lain guna pengembangan.

Unit usaha pondok pesantren Ummul Qura al-Islami Bogor dalam perjalanan bisnisnya, sesuai dengan amanah kyai meski didorong dengan antusias guru/asatidz yang ikut serta membantu memajukan pondok. Dengan unit usaha pesantren sebagai wadah untuk saling tolong menolong dan pendidikan wirausaha bagi santri dan untuk pemenuhan kebutuhan seluruh santri dan masyarakat sekitar.

Unit usaha pesantren telah memiliki prinsip dan nilai dalam beretika bisnis Islam yang menjadikan unit usaha terus melakukan pengembangan. Dalam pengembangannya yang terjadi dalam produksi, pemasaran, persaingan dan laporan keuangan, disesuaikan dengan etika yang diajarkan oleh kyai kepada seluruh masyarakat pesantren.

Unit usaha pondok pesantren modern Sahid Bogor dan pondok pesantren Ummul Qura al-Islami bogor telah menerapkan etika bisnis Islam. Hal ini bisa terlihat dengan adanya prinsip syariah yang telah diajarkan di pesantren dan telah diterapkan dalam lingkungan pesantren 


\section{REFERENSI:}

Afandi, Zaenal. 2019. "Strategi Pendidikan Entrepreneurship Di Pesantren AlMawaddah Kudus." BISNIS: Jurnal Bisnis Dan Manajemen Islam 7 (1): 55. https://doi.org/10.21043/bisnis.v7i1.5191.

Ana Siti Sarpina Saripuddin, Che Omar, and Che Mohd Zulkifli. 2015. "Concept of Business Ethics in Islam - Approach To the Entrepreneur 2 . Sources of Islamic Business Ethics." Journal of Asian Business Strategy 5 (1): 13-18. https://doi.org/10.18488/journal.1006/2015.5.1/1006.1.13.18.

Annam, Rahmad. 2015. “Etos Kerja Dan Produktivitas Kerja Dalam Upaya Menjawab Permasalahan Ekonomi Islam (Perilaku Mendapatkan Uang/Harta)." AlMasharif 3 (2): 36-54.

Anti Wulan Agustini. 2017. “Distribusi Kekayaan Dalam Ekonomi Syariah.” KeIslaman, Kemasyarakatan, Dan Kebudayaan 18 (2): 129-46.

Ar Rahmah, Rizka. 2017. “Etika Dan Manajemen Bisnis Islam (Studi Kasus Di Waroeng Steak and Shake Cabang Sm Raja Medan)." Jurnal Ekonomi Dan Bisnis Islam 2 (2): 1-25. https://doi.org/10.32505/jebis.v2i2.183.

Ardi, Muhammad. 2015. "Etika Bisnis Dalam Ekonomi Islam." Jurnal Syari'ah 3 (1): 7589. https://doi.org/10.30603/ab.v13i2.896.

Arslan, Zeynep. 2009. "Islamic Business Ethics and Its Impact on Strategic Business Decision Making Process of Muslims." Tesis, Business Administration, Simon Fraser University, 77. http://summit.sfu.ca/item/770.

Baehaqi. 2017. "Masjid Sebagai Sumber Pembentukan Kretivitas Manusia Berkarakter." Rausyan Fikr 13 (1): 1311-20.

Barus, Elida Elfi. 2017. “Tauhid Sebagai Fundamental Filsafah Ekonomi Islam.” Jurnal $\begin{array}{llll}\text { Perspektif Ekonomi } & \text { Darussalam } & 2 & \text { (1): }\end{array}$ https://doi.org/10.24815/jped.v2i1.6648.

Darussalam, Andi. 2019. "Paradigma Bisnis Islam Perspektif Hadis." Tahdis: Jurnal Kajian Ilmu Al-Hadis 6 (1): 23-42.

Desiana, Rina, and Noni Afrianty. 2017. “Landasan Etika Dalam Ekonomi Islam.” AlIntaj 3 (1): 119-35.

Elbadriaty, Baiq. 2018. "Implikasi Nilai-Nilai Etika Pada Bisnis Perspektif Al-Qur'an Dan Al-Hadits." Profit: Jurnal Kajian Ekonomi Dan Perbankan 2 (1): 19-34.

Elkarimah, Mia Fitriah. 2016. “Etos Kerja Islami Dalam Mewujudkan Kesejahteraan Sosial." Nurnal Nuha 30 (1): ejournal.staimadiun.ac.id/index.php/annuha/article/download/.../65.

Fadli, Syairil. 2017. “Kritik Seyyed Hossein Nasr.” Jurnal Nalar 1 (1): 69-81.

Falah, Riza Zahriyal. 2018. "Membangun Karakter Kemandirian Wirausaha Santri Melalui Sistem Pendidikan Pondok Pesantren." Tarbawi : Jurnal Pendidikan Islam 15 (2). https://doi.org/10.34001/tarbawi.v15i2.853. 
Fatmasari, Dewi. 2014. "Peran Kewirausahaan Dalam Pemberdayaan Ekonomi Pesantren (Sekilas Tentang Pesantren Ainurrafiq) Desa Panawuan, Kecamatan Cigandamekar Kabupaten Kuningan." Al-Amwal : Jurnal Ekonomi Dan Perbankan Syari'ah 6 367-88. http://www.syekhnurjati.ac.id/jurnal/index.php/amwal/article/view/263.

Fauroni, Lukman. 2009. “Rekonstruksi Etika Bisnis: Perspektif Al-Qur'an.” Iqtisad 4 (1): 91-106. https://doi.org/10.20885/iqtisad.vol4.iss1.art6.

Febriyarni, Busra. 2016. "Fiqh Al-Hadis Etika Bisnis (Tinjauan Kesahihan Dan Pemahaman)." Al Istinbath: Jurnal Hukum Islam 1 (2): 141-60.

Hafidh, Zaini, and Badrudin Badrudin. 2019. "Pesantren Dan Kemandirian Perekonomian: Studi Tentang Kewirausahaan Di Pondok Pesantren Ar-Risalah Cijantung IV Ciamis." MANAGERIA: Jurnal Manajemen Pendidikan Islam 3 (2): 257-67. https://doi.org/10.14421/manageria.2018.32-03.

Hasan, Amin. 2012. "Menyusuri Hakikat Kebenaran: Kajian Epistemologi Atas Konsep Intuisi Dalam Tasawuf Al-Ghazali." Jurnal At-Ta'dib 7 (2): 189-203.

Hasbi, M. 2009. “Konsep Tauhid Sebagai Solusi Problematika Pendidikan Agama Bagi Siswa Madrasah." Jurnal Insania 14 (2): 1-22.

Ichsan, Nurul. 2015. "Kerja, Bisnis, Dan Sukses Menurut Islam." The Journal of Tauhidinomics 12 (2): 167-82. http://journal.uinjkt.ac.id/index.php/tauhidinomics/article/view/8434.

Irsadunas, Yenti Afrida, and Rahmi Khairani. 2018. “Tinjauan Etika Bisnis Islam Dalam Pengelolaan Corporate Social Responsibility." JEBI (Jurnal Ekonomi Dan Bisnis Islam) 3 (2): 145. https://doi.org/10.15548/jebi.v3i2.174.

Issoufou, Chaibou. 2015. “Significance of Islamic Business Ethics." International Journal of Current Research 7 (11): 23362-63.

Kamaruddin. 2018. “Manajemen Strategik Pesantren Dalam Pengembangan Kewirausahaan Di Yayasan Darul Yatama Wal-Masakin (Dayama) Jerowaru Kecamatan Jerowaru Kabupaten Lombok Timur." Tesis Magister Manajemen Pendidikan UIN Mataram. http://ec.europa.eu/energy/res/legislation/doc/biofuels/2006_05_05_consultation _en.pdf\%0Ahttp://dx.doi.org/10.1016/j.saa.2017.10.076\%0Ahttps://doi.org/10.101 6/j.biortech.2018.07.087\%0Ahttps://doi.org/10.1016/j.fuel.2017.11.042\%0Ahttps:// doi.org/10.1016/j.

Khuza'i, Rodliyah. 2005. “Etika Bisnis Dalam Persektif Islam.” Mimbar: Jurnal Sosial Dan Pembangunan $21 \quad$ (1): 36-48. https://www.neliti.com/publications/154164/etika-bisnis-dalam-persektif-Islam.

Maghfur, Ifdlolul. 2016. “Membangun Ekonomi Dengan Prinsip Tauhid.” Malia 7 (2): 213-40.

Maharani, Dewi. 2017. "Penerapan Kejujuran Dan Tanggung Jawab Dalam Etika Bisnis Syariah Pada Wirausaha Muslim Di Kecamatan Medan Marelan." Intiqad: Jural 
Agama Dan Pendidikan Islam 9 (1): 21-29.

Mauludin, Mirshal, and Tri Widianti Natalia. 2018. “Penerapan Pendidikan Ekonomi Kreatif Di Pesantren Sebagai Sarana Untuk Menghasilkan Pribadi Wirausaha Yang Dilandasi Nilai-Nilai Keagamaan." Temu Ilmiah Ikatan Peneliti Lingkungan Binaan Indonesia (IPLBI), C046-51. https://doi.org/10.32315/ti.7.c046.

Muthmainnah, and Nursyamsu. 2017. “Landasan Hukum Islam : Etika Bisnis Syariah Dan Faktor Pengembangannya." Jurnal Syariah V (1): 53-78.

Nadhira, Ulfa Mafthukhatusolikhah. 2016. "Minat Wirausaha Kaum Santri Dan FaktorFaktor Yang Mempengaruhinya (Studi Pada Pondok Pesantren Ar-Riyadh Palembang)." I-Economics 1 (1): 91-121.

Nasyiah, Iffaty. 2014. "Prinsip Keadilan Dan Keseimbangan Dalam Penentuan Nilai Tukar Barang (Harga) Perspektif Islam Dan Hukum Perlindungan Konsumen." Journal de Jure 6 (2): 117-27. https://doi.org/10.18860/j-fsh.v6i2.3205.

Nawawi, Hasyim. 2013. "Islamic Business Ethics between Reality and History." Karsa 21 (1): 96-99. https://doi.org/10.4324/9781315406466-5.

Norvadewi. 2014. "Profesionalisme Bisnis Dalam Islam." Mazahib: Jurnal Pemikiran Hukum Islam $13 \quad$ (2): 175-88. https://journal.iainsamarinda.ac.id/index.php/mazahib/article/view/391/307.

Oktari, Dian Popi, and Aceng Kosasih. 2019. "Pendidikan Karakter Religius Dan Mandiri Di Pesantren." Jurnal Pendidikan Ilmu Sosial 28 (1): 42. https://doi.org/10.17509/jpis.v28i1.14985.

Rahim, Adibah Binti Abdul. 2013. "Understanding Islamic Ethics and Its Significance on the Character Building." International Journal of Social Science and Humanity 3 (6): 508-13. https://doi.org/10.7763/ijssh.2013.v3.293.

Rifa'i, Moh. 2019. “Manajemen Ekonomi Mandiri Pondok Pesantren Dalam Mewujudkan Kualitas Layanan Pendidikan." Profit: Jurnal Kajian Ekonomi Dan Perbankan Syariah 3 (1): 30-44. https://doi.org/10.33650/profit.v3i1.538.

Rofiah, Khusniati. 2014. “Urgensi Etika Di Dalam Sistem Bisnis Islam.” Justicia Islamica $11(2)$.

Rohmah, elfi yuliani. 2016. "Mengembangkan Karakter Tanggungjawab Pada Pembelajar." Al-Murabbi 3 (1): 36-54.

Saifuddin. 2008. “Kajian Agama Dan Filsafat Tentang Kebenaran." Islam Futura VII (2): 73-83.

Saleem, Maimoona, Ayaz Khan, and Muhammad Saleem. 2014. "Business Ethics in Islam." The Dialogue xiii (3): 1-256. https://doi.org/10.4337/9781781006733.

Sariati, Ning Purnama, and Binti Mutafarida. 2019. "Pesantren Dan Konsumsi Halal Santri (Studi Kasus Di Pesantren Syarif Hidayatulah Rejomulyo Kediri)." Prosiding Nasional 2: 193-212.

Sudarsih, Endang. 2010. “MENGEMBANGKAN WIRAUSAHA DI PONDOK 
PESANTREN Endang Sudarsih." Jurnal Sosial Humaniorah 3 (1): 70-77. https://www.researchgate.net/publication/316924708_MENGEMBANGKAN_W IRAUSAHA_DI_PONDOK_PESANTREN/link/59807e6a0f7e9bd660eb4983/dow nload.

Suhadi, and Mursal. 2015. "Implementasi Prinsip Islam Dalam Aktivitas Ekonomi: Alternatif Mewujudkan Keseimbangan Hidup." Jurnal Penelitian 9 (1): 67-92. https://doi.org/10.21043/jupe.v9i1.851.

Sujianto, Agus Eko. 2011. "Modernitas Kyai Dan Implikasinya Terhadap Pendidikan Kewirausahaan Di Pondok Pesantren." Millah 11 (1): 153-70. https://doi.org/10.20885/millah.vol11.iss1.art7.

Suwandi, Andi. 2017. “Commerce Ethics of Muhammad PBUH' and Universal Values in Era of Prophet Hood." JESI (Jurnal Ekonomi Syariah Indonesia) 7 (1): 49. https://doi.org/10.21927/jesi.2017.7(1).49-60.

Taufiqurrochman, R. 2014. “Pendidikan Masyarakat Berbasis Masjid.” Uin Malang, 110. http://repository.uin-malang.ac.id/799/2/masjid.pdf.

Tiakoly, Kataruddin, and Abdul Wahab. 2019. "Penerapan Etika Bisnis Islam Pada Usaha Pedagang Barang Campuran Di Pasar Tradisional Gamalama." Jurnal Iqtisaduna 5 (1): 102-23.

Wakhidah, Zahrotul. 2017. "Pengaruh Penerapan Etika Bisnis Islam Terhadap Customer Retention Pada Baitul Mal Wat Tamwil (BMT) Tumang Boyolali." Tesis Magister Ekonomi PASCASARJANA INSTITUT AGAMA ISLAM NEGERI (IAIN) SURAKARTA.

Wartoyo. 2018. "Etika Bisnis Islam: Konstruksi Nilai Keseimbangan Dan Kemanusiaan." Al-Amwal : Jurnal Ekonomi Dan Perbankan Syari'ah 10 (2): 229-43. https://doi.org/10.24235/amwal.v10i2.3369.

Windari. 2015. "PERDAGANGAN DALAM ISLAM.” Al-Masharif: Jurnal Ilmu Ekonomi Dan KeIslaman 3 (2): 19-34. 
Dwi Irfan Cahyo

20 -Fakultas Syariah dan Hukum UIN Syarif Hidayatullah Jakarta 